\title{
DISTRIBUTION PAYOUT PRACTICES AND THE COLLAPSE OF A-REITs
}

\section{LAURA CUMMINS and HUGH ZOCHLING University of Technology Sydney}

\section{ABSTRACT}

In the lead up to the Global Financial Crisis, A-REITS pursued aggressive distribution practices. Payout ratios significantly in excess of $100 \%$ of underlying earnings became common place, funded largely from increased borrowings. The GFC painfully exposed the unsustainability of this practice. A-REITs were punished when the global debt markets froze and property values crashed, leading to massive equity destruction for over geared AREITs. This research explores the pre-GFC distributions practices of AREITs. Annual report financial data analysis and semi-structured interviews with five industry experts were conducted to examine A-REIT distribution practices. The results reveal a clear systematic decline in the relationship between underlying earnings and distributions. It is further discovered that the since abandoned practice of distributing un-realised profits was designed to boost share prices. Paradoxically, it eventually led to their decline and the A-REIT sector's demise.

Keywords: A-REITs, distributions, debt, underlying earnings, retained earnings, Global Financial Crisis

\section{INTRODUCTION}

Australia's Real Estate Investment Trust (A-REIT) sector has experienced a turbulent decade. During that time, many A-REITs were transformed from a largely low risk/low return, stable rental income based investments to much higher risk and return investments. They were punished in the Global Financial Crisis (GFC) as a consequence.

A-REITs traditionally earned profits and paid distributions from their largely Australian investment property rental income. However, in the mid-2000's, A-REITs began to pursue higher earnings and distribution growth. They increasingly introduced other income streams such as development, funds management, offshore investment and even mezzanine lending. Following the introduction of the International Financial 
Reporting Standards (IFRS) in 2005, A-REITs also began to account for unrealised gains in property values as income, as changes to the "fair value of investment properties" moved from the Balance Sheet to the Profit and Loss Statement. These combined new sources of income were lucrative and gave the A-REITs higher earnings growth but also increased risk.

At the same time, credit became cheaper and more plentiful. Banks allowed A-REITs to expand their balance sheets with higher debt to equity ratios. A-REIT sector gearing peaked at almost $45 \%$, up from around $30 \%$ at the beginning of the decade. A-REITs took advantage of higher gearing levels to fund distribution pay-outs exceeding underlying earnings.

\section{Figure 1: A-REIT sector gearing ratio (debt to equity)}

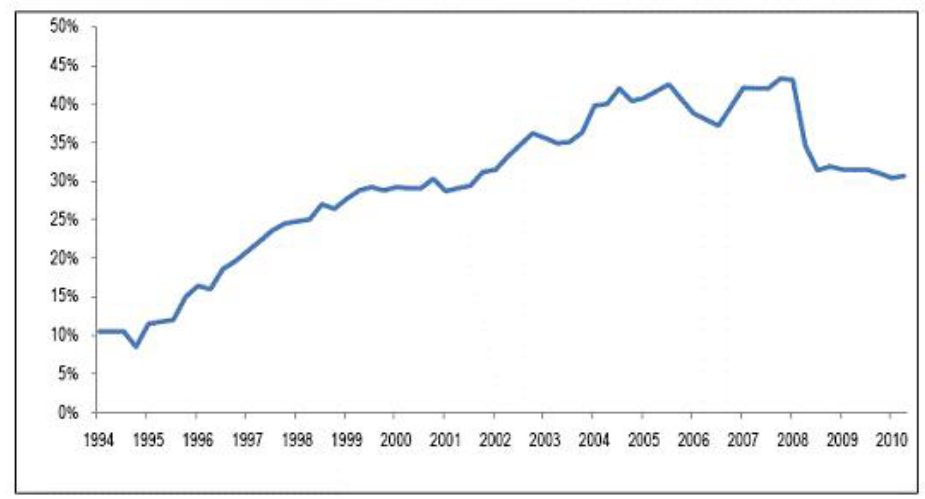

Source: JP Morgan

At the same time, the increased availability and lower cost of debt also contributed to ballooning property values, as investors, particularly A-REITs, could afford to and did pay more for properties. 


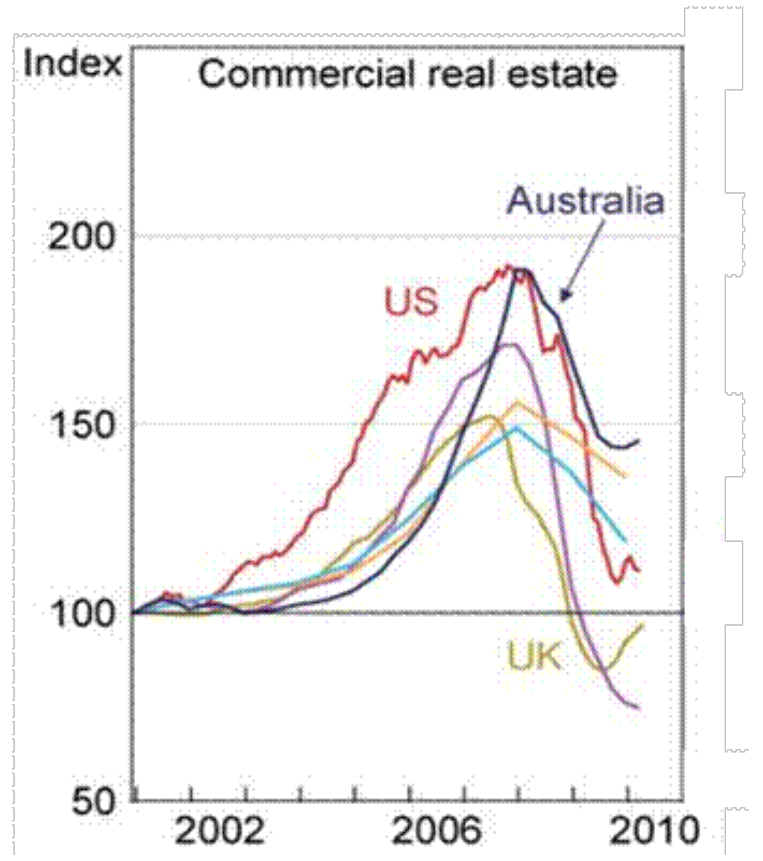

Sources: APM, Bloomberg, JLL, Thomson Reuters

This created a cycle of increasing property values and debt levels, as A-REITs took advantage of resultant higher portfolio values, by leveraging against the gains to boost dividend pay-outs and acquire more assets.

Distributing more than underlying earnings became a serious problem in the A-REIT sector following the onset of the GFC. The practice was proven unsustainable, as it involved paying out unrealised gains as income while relying on increasing asset values and availability of cheap debt for funding. When property markets crashed in the GFC, most A-REITs experienced large declines in portfolio values and even greater equity destruction. Distributions were reduced or suspended altogether while A-REITs undertook debt reduction and re-capitalisation.

In response, A-REITs have dramatically changed their risk profile and distribution policies from the constant and 'at all cost' striving for earnings and distribution growth to a more "back to basics" business approach and distribution payouts in-line with underlying earnings. 
In this paper, the significance of the changes to A-REIT earnings and distribution practices are analysed through decomposition of financial statements across the decade for 10 major A-REITs. The reasons for the changes are then explored through semi-structured interviews with 5 industry experts.

\section{LITERATURE REVIEW}

There has been considerable research into the dividend payout policies of firms and some of these studies, such as Wang et al (1993), Chan et al (2003) and Hardin and Hill (2008) have focussed on REITs. The majority of these use data from the United States where there are different taxation regulations regarding the compulsory payout of income returns. However, the basic trust structure and regulatory environment is similar enough for these studies to be applied to A-REITs. The breakdown of the income and capital components of dividends is not well researched. The payout policy of a REIT affects growth, long-term sustainability and influences capital investment and there have been few key quantitative studies researching this topic. REIT dividend payment is shown to be discretionary and determined by Management.

\section{REIT returns}

Total returns are the sum of capital returns and income returns. Historically, income returns for traditional property based A-REITs are the rental monies received from properties' tenants net of operating costs. Capital returns are the gains received from selling their assets. The recent changes in the industry have added extra income return sources to total returns. Managing property, developing property and financial hedges were shown to be increasing returns, and simultaneously increasing risk and diminishing the defensive attributes of A-REITs (Newell \& Tan, 2005). The reliance on steady rental income fell from $96 \%$ in 2000 to $87 \%$ in 2004 (Oliver, 2004), which shows a large shift in the investment paradigm and management of A-REITs.

\section{Dividend policy}

Traditionally, distributions from A-REITs have been sourced from the income returns with capital growth distributed when assets are sold. A-REITs distribute the majority of income returns as they are not subject to income tax if they are passed on to unitholders who receive the tax benefits of property ownership. Distributions are an indication of future performance (Kallberg et al, 2003). A fall in distributions can have a large effect on the share price. REITs will pay out conservative dividends if they predict a higher volatility in future earnings to save cash and ensure a consistent pay out amount (Bradley et al, 1998). The risk of future earnings is related to specific cash flows, not systematic or market related risk. Bradley et al (1998) analyse this volatility in terms of: 
- Leverage, measured by the debt to equity ratio;

- Diversification, geographic and property classes; and

- Changes in net tangible asset valuation (NTA).

Any distribution in excess of the reported net income is attributable to the decisions of Management (Hardin and Hill, 2008). They also found that REITs use short-term debt to finance dividends in excess of net income if they are supported by existing and prospective future operating cash flows.

Hardin and Hill (2008) believe well-performing REITs should be rewarded by being allowed to retain some earnings for investment purposes. Other researchers agree with this idea, however, the practice is not apparent in the Industry. This will be discussed further.

Wang et al (1993) ask why REITs simultaneously pay out dividends and raise money in capital markets given the high cost associated with raising capital. They found that REITs were paying out $165 \%$ of compulsory payments, showing that payout policies of REITs, which were previously regarded as well regulated, are in fact considerably up to the discretion of Management. They conclude dividend policies are at least partially determined by agency costs where there is a cost for information asymmetry and it can be cheaper for Management to be monitored by capital markets.

\section{Expansion and long-term sustainability}

Chan et al (2003) find that finite life REITs pay out higher distributions than infinite life REITs, as they do not need to conserve cash for reinvestment because they have a specific lifespan. A-REITs listed on the Australian Securities Exchange (ASX) are subject to very long fixed terms governed by their trust deeds, typically 80 years or more. Therefore they have characteristics of infinite life REITs and should theoretically be conserving cash to reinvest in assets. Property as an asset class requires reinvestment for maintenance capital expenditure on existing properties and this is generally covered by the depreciation tax deduction. Properties' quality and functionality, and consequently their income generating potential, decline over time without capital expenditure. REITs must reinvest to maintain future earnings.

Modigliani and Miller (1958) outline the market value maximisation approach, which is all investment and capital structure decisions should be made to increase the longterm market value of company. Whilst increasing dividends will do that in the shortterm, long-term sustainability requires reinvestment. Modigliani and Miller also argue that the managers should not take into account the current unit-holder preferences, but those of the potential unit-holders who will be attracted to the good management of the company. Interestingly, Modigliani and Miller believe shareholder value is determined by profit, not just distributions, and the division between the two "in any period is a mere detail". 
Hardin and Hill (2008) found that REITs do not have sufficient cash flow to substantially increase assets under management and must rely on injections of money from capital markets instead. From capital markets, REITs obtain short-term debt, long-term debt and additional equity. They believe REITs must act in the way that best reduces agency costs associated with raising debt and equity capital because of their reliance on capital markets. This follows on from Wang et al (1993) who found shareholders prefer to receive high dividends and use the capital markets to assess management performance, usually via the scrutiny associated with public capital raisings.

\section{Capital structure}

Capital structure comprises the financing components of a firm, namely debt and equity, and the related ratio thereof. Capital to expand and finance REITs can be secured through:

- Debt;

- Dividend Reinvestment Plans (DRPs);

- Retained earnings; or

- Equity offerings.

Whilst retaining earnings can be the easiest and most cost-effective way to increase company equity, this practice is not usually adopted due to the perceived impact lowering distributions has on share price (Bradley et al, 1998). Ott et al (2005) found that between 1981 and 1999 only 7\% of REIT investment was derived from retained earnings in comparison to $70 \%$ for industrial companies. The majority of REIT investment came from equity and long-term debt (84\%) and the remainder from preferred stock and short-term debt (9\%) (Ott et al, 2005). There is limited research available on DRPs and their use in the REIT industry.

Studies have been done on the financing decisions of REITs to determine why they choose certain capital structures. The three theories tested are pecking order theory, trade-off theory and market timing theory (Feng et al, 2007 and Boudry et al, 2010). The pecking order theory looks at obtaining finance through the option of least resistance. For most firms the cheapest finance to arrange is retained earnings, and then debt finance, with equity being the most expensive. However, as A-REITs require a flow-through of income to avoid massive tax penalties, they struggle to finance expansion with retained earnings because they distribute most of their income (Hardin \& Hill, 2007 and Boudry et al, 2010). As shown by Ott et al (2005), they instead rely heavily on injections of equity and long-term debt. If the pecking order theory was used, A-REITs would retain capital where possible.

The trade-off theory is when a balance is found between tax-deductible interest payments and the cost of financial distress (Feng et al, 2007). There are advantages Pacific Rim Property Research Journal, Vol 17, No 4, 2011 
and disadvantages to both debt finance and equity finance and there will be an optimal ratio whereby any increase in the use of one will increase the overall cost of capital.

The market timing theory is when firms issue shares at high prices and re-purchase at low prices. Boudry et al (2010) describe REIT share price as the value the public equity market places on their cash flows and REIT Net Asset Value (NAV) as the private equity measure of the same cash flows. If the stock price is high in relation to the NAV then public equity will be the cheaper source of finance and REITs will be more likely to issue equity raisings.

Boudry et al (2010) found that market timing was the best supported theory. REITs are most likely to issue equity after high returns are achieved and when there is a suitable difference between the public and private equity markets. They believe managers do not use the market timing theory because the assets are overvalued, but simply because it is cheaper. The pecking order theory is not prevalent from their research due to the non-reliance on retained earnings and findings that firms that return capital are more likely to issue equity.

\section{Managerial impact}

The impact of managerial motives is an interesting point of discussion. Ghosh and Sirmans (2006) question whether director interests are aligned with shareholders' interests in REITs and whether they perform differently if they are given cash compensation or 'long term rewards' in the form of share ownership. Corporations are monitored internally by directors and externally monitored by the threat of hostile takeover. Ghosh and Sirmans (2006) believe this motivates managers to either perform well or to entrench themselves so they cannot be dismissed.

Ghosh and Sirmans' findings can be briefly summed up as following:

1. Poor performance results in a higher Distribution payout;

2. A larger Board size will deliver a smaller Distribution payout;

3. The longer the Chief Executive Officer (CEO) tenure, the higher the Distribution payout; and

4. CEO ownership will result in lower Distribution payouts.

It is claimed high dividends are a way poor performing managers attract investors; and managers who perform well do not need to pay high dividends. This is consistent with theory that if managers are believed to be acting in the best interests of the unit-holder and have shown they can effectively create shareholder wealth then retained earnings are "regarded as equivalent to a fully subscribed, pre-emptive issue of common stock" (Modigliani and Miller, 1958). Ghosh and Sirmans (2006) believe unit-holders require higher returns from poor managers, because if they did retain cash they would spend it on "value-destroying projects". 
Ghosh and Sirmans (2006) observe a larger board size will make management more independent, resulting in lower distributions.

The third finding relates to the negative perception that the longer a CEO serves, the more entrenched he or she becomes. The unit-holders will then demand higher dividends to protect their interests.

The fourth finding shows the positive relationship between market capitalisation to book value ratio and is a proxy for growth opportunities. Ghosh and Sirmans find managers perform better if they are unit-holders as they are motivated to have good long-term growth. CEOs with ownership are more likely to seek out investments with long-term profitability meaning ownership would help the implementation of the market value maximisation approach set out by Modigliani and Miller in 1958.

Payout policies of REITs and their influences have been researched widely. However, there are still gaps in the literature regarding the capital and income components of distributions. The payout policies often determine the capital structure and the ways in which REITs will raise money to expand and are therefore important for the long-term sustainability of the trust. The dividend policy changes that have occurred recently in the A-REIT industry are apt for study.

\section{METHODOLOGY AND DATA}

\section{Background}

As the purpose of this study is to explore the nature, rather than extent, of the practice of distributing non-free cash flow profits, a combination of qualitative and quantitative approaches were used. The grounded theory works well when there is not a large body of knowledge in the area and the issue is current. Most studies done on A-REITs have been quantitative correlation studies on historic data and are somewhat out-dated due to recent turmoil in the sector. Additionally, there is very little literature regarding behavioural considerations of REIT distribution decisions. Qualitative research with a grounded theory approach was chosen to fill some of the large gaps in the current body of knowledge.

The objects are to:

1. Explain the nature of the problem of A-REITs distributing unrealised gains as distributions to shareholders;

2. Investigate why the above occurred; and

3. Consider how industry practice has changed due to recent happenings in the world economic situation. 
The research problem and extent of the phenomena was determined by analysis of quantitative data and the nature, causes and effects of the problems are explored using a qualitative approach and semi-structured interview technique. The outcomes of this research will add to the small body of knowledge in the area, leading to a better understanding of the A-REIT distribution process and awareness of past mistakes.

\section{Financial data analysis}

Analysis of the financial statements of ten leading A-REITs was performed, looking at the differences and correlations between reported profit and loss, revaluations and distributions. The A-REITs were chosen either for their size or their performance during the GFC. The financial annual reports from 2000 to 2010 were obtained (where possible) and the appropriate data extracted. Regressions were performed to find the correlation between distributions and underlying earnings data.

\section{Semi-structured interviews}

Once a trend was found from the data, the reasons could then be explored qualitatively. A semi-structured technique was used so any leads that emerged could be followed up and to obtain a depth of knowledge on the interview topic. Interviews were conducted in October 2010 with two A-REIT managers (RM1 and RM2), two investment fund managers (FM1 and FM2) and one equities analyst (EA) to obtain rich data. They were chosen because of their experience (i.e. +10 years each) and to show a variety of views, A-REIT association and investment interest. All interviewees participated anonymously.

The industry experts were asked the following questions:

- What are the benefits of giving out non-cash earnings (i.e. unrealised earnings) ?

- Do you think giving out non-cash earnings is a sustainable practice?

- Do you believe distributions are 'an indication of future earnings'?

- According to Modigliani and Miller's theory, retained earnings and distributions should both be considered income for unit-holders - as retained earnings indicate an investment in future earnings. Do you think either investors or managers in the A-REIT sector consider this theory?

- Ghosh and Sirmans (2006) find that poor performing REITs have higher payout policies, as though investors need an incentive to hold shares in that REIT. Do you think this is apparent in the A-REIT sector or highlighted in the GFC?

The interviews were transcribed and the data sorted into a spreadsheet for ease of analysis. Answers to the interview questions were then assessed for trends and differences. Many common themes and examples arose, but the industry experts all had varying viewpoints, giving a range of answers for some of the questions. 


\section{RESULTS}

The change between the correlation coefficients $(\mathrm{R})$ over the past decade can be seen in Table 1 below. Between 2000 and 2004, the 10 A-REITs analysed averaged a correlation of $\mathrm{R}=0.821$ showing a positive correlation between underlying earnings and distributions. This correlation coefficient fell to $\mathrm{R}=0.389$ for the period 2005 to 2009 indicating this data is uncorrelated. The fall in the coefficient value signifies a substantial change in the sector during this time period.

\section{Table 1: Correlation coefficients for AREIT underlying earnings and} distributions

\begin{tabular}{lccc}
\hline & $\begin{array}{c}\mathbf{2 0 0 0 - 2 0 1 0} \\
\text { (or all available } \\
\text { years) }\end{array}$ & $\mathbf{2 0 0 0 - 2 0 0 4}$ & 2005-2009* \\
\hline Commonwealth Property Office & 0.869 & 0.998 & 0.260 \\
Fund (CPA) & -0.281 & 0.498 & 0.175 \\
GPT Group (GPT) & 0.623 & 0.867 & 0.585 \\
Mirvac Group (MGR) & 0.006 & $\mathrm{~N} / \mathrm{A}^{\wedge}$ & -0.186 \\
Goodman Group (GMG) & 0.786 & $\mathrm{~N} / \mathrm{A}^{\wedge}$ & 0.940 \\
Dexus Property Group (DXS) & 0.497 & 0.989 & 0.145 \\
ING Office Fund (IOF) & 0.445 & 0.685 & 0.383 \\
Stockland Group (SGP) & 0.538 & $\mathrm{~N} / \mathrm{A}^{\wedge}$ & 0.754 \\
Westfield Group (WDC) & 0.948 & 0.935 & 0.582 \\
CFS Retail Property Trust (CFX) & -0.004 & 0.778 & 0.248 \\
Centro Properties Group (CNP) & $\mathbf{0 . 4 4 3}$ & $\mathbf{0 . 8 2 1}$ & $\mathbf{0 . 3 8 9}$ \\
AVERAGE & &
\end{tabular}

*2010 was not included: to make the time series 5 years each; because not all A-REITs have released 2010 results yet; and many changed their payout policies in the 2010 financial year

$\wedge$ A-REITs not yet listed

Several of the trusts retained relatively stable correlations over the time period and others, such as Centro Properties Group and Commonwealth Office Trust, went from strongly correlated to uncorrelated. The results are very significant and the reasons for the changes should be explored.

The full statistical data can be sourced from the authors.

\section{Interview results}

The industry experts all gave similar reasons for the trend of paying out more than underlying earnings which emerged from the statistical data. These reasons were 
increasing distribution yields and share price. The higher yields benefited shareholders and made equity raisings more attractive to potential investors (EA and RM2). Both fund managers saw the higher distribution as a way to increase share price, which allows access to cheaper finance and thwarts potential takeovers. RM1 said they did it to keep up with everyone else who was giving out high distributions; there was competition for capital and they did not want to get left behind. Increases in earnings growth were all important at the time and giving out high distributions was an easy and cheap way to fund growth.

Similarly, all the industry experts interviewed agreed the practice was unsustainable and this was exposed by the impact of the GFC. RM1 said when you're at the top of the cycle, you never think, “this isn't sustainable, you just go with it.” RM2 observes it is only sustainable while asset values are increasing and banks keep lending money and if you were to attempt this practice now, analysts will "slaughter you" and banks will not give the Trusts money. Interestingly, when asked this question, EA, FM1 and FM2 all referred to the limited detail on maintenance capital expenditure and depreciation figures within financial statements. They obviously see this as an area where REITs lack transparency. The amount a trust depreciates their assets and spends on maintaining their assets annually affects the long-term sustainability of the trust.

From the interviews, it was noted distributions are not always regarded as an indication of future earnings. FM1 believes the market is making it clear it believes there is a difference between distributions and earnings and this is one of the big changes the sector is coming to grips with. FM2 said while dividend yield was used to compare trusts in the early 1990s they no longer look at it as a value indicator as the trusts have such diverse payout ratios. Similarly, RM2 says distributions used to be excellent indicators of future earnings but now due to leverage and other income streams, one year's earning does not really indicate the following year's earnings. However, EA makes the point directors must be comfortable with what they are paying out as they do not want a fluctuating unit price and RM1 notes "in the good times everyone assumes it is all positive so in that sense, yes, they are seen as an indicator”. RM1's trust forecasted earnings growth, which helps to explain why distributions were higher than underlying earnings; they could pay out the forecasted growth in advance because debt was so cheap.

Modigliani and Miller's theory of retaining earnings and its use in the A-REIT sector had mixed reviews. EA and FM2 treat retained earnings as income if the managers have a positive use for the money internally. RM1 can see the benefits of this theory as from a trust manager perspective it stops them borrowing money and raising equity. However, RM1 knows most of the investors bought their shares for the distribution income and value their holding accordingly. RM1 and FM1 both gave the example if REIT distributions are steady at $100 \%$ of taxable earnings then are reduced to $80 \%$, the share price will fall accordingly. RM2 says the practice of retaining earnings is not 
apparent because investors hold these shares to receive an income stream. If they want dividends to be reinvested, they can use Dividend Reinvestment Plans (DRPs).

The industry professionals interviewed agreed many REITs showed signs of Ghosh and Sirmans' theory that poor performing REITs have a higher payout ratio but the market is aware of this practice now. EA and FM2 both said low performing REITs have high payout ratios because they cannot prove they can reinvest retained earnings wisely. RM1 names Centro as the 'classic example' of a REIT paying out more distributions than earnings, where you could not work out what you were getting for your unit. EA sees Westfield as an example where the REIT has a lower payout ratio as they have proved they can reinvest and grow the company. RM2 believes this theory was more apparent in the US REIT market. FM2 notes, whilst they do not base investment choices on dividend yields, there are many REITs, such as Colonial First State Retail Trust, with a high payout ratio, which are not poor performing.

\section{DISCUSSION}

Bradley et al, (1998) find that REITs will lower their distributions to conserve cash if they predict a higher volatility in future earnings. Cash is conserved to supplement future distributions, as a fall in dividend payout will affect a REITs share price, as that is how investors value their holding. However A-REITs do not seem to have considered this as before the GFC they were consistently giving out more than underlying earnings, seemingly only concerned with the short-term results of their actions. Bradley et al's three measures of volatility: the debt to equity ratio, diversification and changes in NTA are the very things A-REITs exploited to pay out a higher distribution. When there were positive increases in the NTA value, rather than lowering the debt to equity ratio, REITs used the additional "equity" to increase distributions to shareholders. When the credit crunch occurred in late 2007, asset values fell and banks called in their loans. Distributions fell dramatically, and combined with the large and discounted equity raisings, there was a consequential fall in the share prices.

RM1's answers agree with Hardin and Hill's (2008) research where they found shortterm debt is used to finance distributions in excess of net income. Whilst distributing more than underlying earnings, RM1's trust were simultaneously forecasting earnings growth for the following years. However, in many cases, REIT managers' reliance on readily available and cheap debt became unsustainable, excessive and irresponsible. The constant striving for earnings growth influenced REIT managers to make decisions to benefit shareholders and share price in the short term. These short-term decisions were not necessarily profitable in the medium to long term. 
The observations of the industry experts and the actions of the markets agree with the findings of Wang et al (1993). Shareholders prefer the high payout ratios so they can use capital markets to monitor management decisions. Whilst there are benefits to retaining earnings, investors traditionally invest in REITs for the stable, high-income returns. DRPs allow them to reinvest if they believe the REIT is able to manage the money well and grow the company.

Modigliani and Miller's market value maximisation theory is seen to have benefits, but its use in the A-REIT sector is not observed by the industry experts to be widely apparent. The most common reason that arose was most shareholders are retail investors who buy shares in REITs for the steady income dividends and that is how they price their holding. Trust tax law encourages a high payout of income earnings through high taxation of retained earnings. REITs therefore tend to pay high distributions and access the equity market if capital is required. If the tax structure of REITs were different, there could be less distribution expectation from investors, allowing for more retained earnings for reinvestment and capital growth.

According to Chan et al (2003), as A-REITs are effectively infinite life REITs, they should conserve cash to fund reinvestment. If more than realised net income is being distributed, as had been the case in Australia until recently, dividends are effectively being debt funded. This reliance on debt is only sustainable as long as debt is cheap and available and property values continue to increase. This was shown in the financial data where distributions were uncorrelated to underlying earnings between 2005 and 2009. A-REITs have since reverted to only distributing free-cash flow profits.

The results show A-REITs prefer to pay out high distributions to maintain a high yield and support the share price, thereby making the stock more attractive to investors. To achieve this, REITs looked for new income streams to increase their distributions. Property and funds management, financial hedging, offshore investment and development successfully gave the A-REITs higher income sources, although at a cost of higher risk.

However, it was changes in the financial reporting standards in 2005 that paved the way for the substantial deviation in A-REIT distribution practices. The International Financial Reporting Standards (IFRS) were introduced in Australia in 2004/2005. Amongst other changes, movements in the "fair value of investment properties" went from the Balance Sheet to the Profit and Loss Statement. Any positive asset revaluations boosted the reported profits of the A-REITs.

Simultaneously, the global economy was awash with cheap and easily accessible debt and property values were rapidly rising. For some A-REITs, their interest cost was just 25 basis points over bank bill rates, making debt cheaper and easier to access than 
equity. These conditions allowed A-REITs to achieve pay out significant non-realised earnings.

The interviewees agreed that IFRS exacerbated the practice of paying out more than free-cash flow profits. It was agreed institutional investors should know to strip back revaluations from financial statements to find underlying earnings. However, whilst retail investors also had access to all the relevant information, the interviewees agreed they could have been misled as to the actual performance of the REIT and the origin of the distribution payout.

The research agrees with Boudry et al's (2010) findings that the market timing theory of capital structure is the most commonly used by A-REITs. They tend to give high distributions so the market values their share price highly and they can issue equity raisings. They observe that if the share price is high in relation to the NAV then public equity will be a cheaper source of finance. However, Boudry et al (2010) do not acknowledge the share price may be artificially overvalued due to the distribution of non-free cash flow earnings and the effect this has on the long-term value of the stock.

\section{CONCLUSION}

As indicated by the research, increasing earnings and distributions is key to a higher share price in the REIT sector. In the pre-GFC period of the last decade, A-REIT managers were encouraged by the market to find ways to boost earnings and distribution growth beyond that afforded by the traditional source of investment property income. Consequently, A-REITs pursued income streams from nontraditional and increasingly risky sources such as development, funds management and even mezzanine lending.

A-REITs also took advantage of changes to accounting standards in 2005 that enabled un-realised gains in investment portfolio values to be treated as profit, while exploiting liberally available and cheap debt to fund distributing those unrealised gains.

The global surfeit of cheap debt had a cyclical effect on property markets, producing a price bubble:

- The increasing level and availability of debt led to higher asset prices and valuations;

- $\quad$ Allowing A-REITs to refinance and access more debt capital;

- With refinancing at higher debt to equity ratios allowing access to more debt capital;

- $\quad$ Leading to higher asset prices and valuations. 
The use of debt under these circumstances to fund distribution of un-realised profits was only sustainable whilst asset values continued to increase. The GFC brought an end to the magic-pudding-like approach to distributions that had seduced the sector. The A-REITs evidently did not factor in the possibility or consequences of a credit squeeze and fall in asset values, focussed purely on short-term earnings and distribution growth to support share prices. When the GFC hit, the highly geared AREIT sector was savaged. Paradoxically, the practices employed to boost share prices led to their demise.

Since the GFC, A-REITs have adopted a back-to-basics approach to business, largely reverting to their traditional passive nature and sources of income. A more conservative approach to distribution payout ratios has now been adopted based around cash earnings. The use of debt to fund distributions has now ceased and gearing levels have also been significantly reduced an important acknowledgement by the A-REITs of the unsustainability past practices.

Collectively these actions have simplified the A-REIT sector and represent a lower risk approach more focussed on long-term sustainability. While financial restoration of the A-REIT sector is largely complete, it may be much longer before the credibility of the once world leading sector is also restored.

\section{REFERENCES}

Boudry, W., Coulson E., Kallberg J. and Liu C. (2010), On the Hybrid Nature of REITs. working paper.

Boudry, W., Kallberg J. and Liu C. (2010), An Analysis of REIT Security Issuance Decisions, Real Estate Economics 38(1):30.

Bradley, M., Capozza D. and Seguin, P. (1998), Dividend Policy and Cash-Flow Uncertainty, Real Estate Economics 26(4):25.

Charmaz, K. (2004), Grounded Theory, In Approaches to Qualitative Research: A Reader on Theory and Practice, eds. Nagy S., Hesse-Biber and Leavy, P. New York: Oxford University Press.

Feng, Z, Ghosh, C. and Sirmans, C.F. (2007) On the Capital Structure of Real Estate Investment Trusts (REITs), Journal of Real Estate Finance and Economics 34:25.

Ghosh, C. and Sirmans, C.F. (2006) Do Managerial Motives Impact Dividend Decisions in REITs, Journal of Real Estate Finance and Economics 32:29. 
Hardin, W and Hill, M. (2008), REIT Dividend Determinants: Excess Dividends and Capital Markets, Real Estate Economics 36(2):22.

Kallberg, J., Liu, C. and Srinivasan, A. (2003), Dividend Pricing Models and REITs, Real Estate Economics 31(3):16.

Kumar, R. (2005), Research methodology: a step by step guide for beginners. 2 Edition. Sydney: Pearson Education Australia.

Modigliani, F. and Miller, M. (1958), The Cost of Capital, Corporation Finance and the Theory of Investment, The American Economic Review 48(3):37.

Newell, G. and Yen, K. (2005), Factors influencing the performance of Listed Property Trusts. Pacific Rim Real Estate Society. Melbourne.

Oliver, S. (2004), Listed Property Trust Changes - Implications for investors.

Ott, S., Riddiough, T. and Yi, H. (2005), Finance, Investment, and Investment Performance: Evidence from the REIT Sector, Real Estate Economics 33(1):23.

Strauss, A. and Corbin, J. (1998), Basics of qualitative research: techniques and procedures for developing. 1st Edition.

Wang, K., Erickson, J. and Gau, G. (1993), Dividend Policies and Dividend Announcement Effects for Real Estate Investment Trusts, Journal of the American Real Estate and Urban Economics Association 21(2):17.

\section{Email contact: hugh.zochling@uts.edu.au}




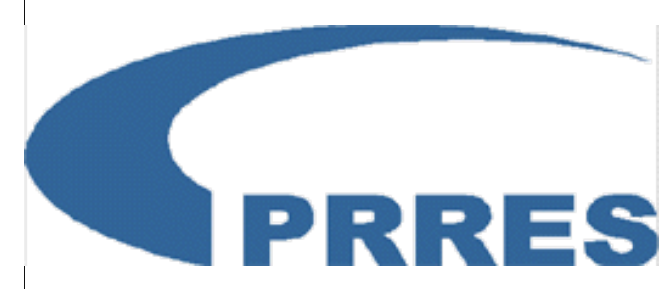

\title{
Pacific Rim Property Research Journal
}

\author{
The official journal of the Pacific Rim Real Estate Society
}

A refereed journal in property ISSN 1444-8921

\section{Purpose of the Journal}

The Pacific Rim Property Research Journal is the official quarterly refereed journal of the Pacific Rim Real Estate Society (PRRES) and is intended to offer academics and practitioners a forum for the dissemination of the latest ideas in property research in the Pacific Rim region. There are 4 issues each year and subscription is included with PRRES membership or via separate subscription. The journal publishes applied property research relating to all aspects of property. Papers must examine applied property issues in a rigorous manner, and should not merely be descriptive.

\section{Online Details and Articles}

This website has up-to-date issues of the journal. To access these simply select the Volume and Number below. This will open a page of details including the journal reference, author, title, keywords and abstract. To open a specific article click the View the Full Paper link. Volumes back to 2000 are online. For older volumes the details, but not the full paper are available.

If you are making a more general search for articles you should open the Search link and search by author, topic or keyword. This will search the entire PRRES data base of articles that includes items from the Journal as well the annual PRRES Conference.

\section{View Current and Previous Issues of PRPRJ}

Volume 17 Number 4 December $2011 \div$ Submit

\section{Review of Articles}

Papers are assigned anonymously by the editor to two specialist referees. These referees will submit detailed referee's regarding the suitability of the paper for publication and recommended revisions, if required. Referees are required to submit their reports within four weeks, the turn-around time for papers is approximately six weeks. To facilitate the refereeing process and communication, email is the preferred procedure for submission of papers. Each issue will attempt to reflect a diversity of property topics. The final decision on the content of specific issues will be made by the editorial board. Special issue topics will be determined by the editorial board and announced with sufficient lead-time. Click here for details on how to to submit an article.
Editor
Professor Graeme Newell
Editorial Chairman
University of Western Sydney
Associate Professor Angelo Karantonis University of Technology, Sydney

\section{Submission Requirements}

Authors should submit their papers, with all files readable through Microsoft Office applications. Papers should be no more that 5,000 words. All papers should be submitted, preferably as email attachments, to:

\author{
Professor Graeme Newell \\ Editor, Pacific Rim Property Research Journal \\ School of Construction, Property and Planning \\ University of Western Sydney \\ Locked Bag 1797 \\ Penrith South DC NSW 1797
}

Tel: $61-2-98524175$

Fax:61-2-9852 4185 
Email: g.newell@uws.edu.au

\section{Format of papers}

1. An abstract of no more than 100 words is required, summarising the research issue and key findings.

2. Detailed mathematical proofs are not required; equations should be centred and numbered consecutively.

3. End notes and appendices should be kept to a minimum.

4. Referencing should use the Harvard system; see previous PRPRJ copy for format.

5. Tables and Figures should be kept to the essential number needed and integrated into the text appropriately.

6. Submitted papers for refereeing should be anonymous; a separate cover page is needed, giving full details of authors' names, affiliations, addresses and email addresses.

7. See previous copies of PRPRJ articles for typical format of presentation.

\section{NOTE Essential Requirements for Publication}

It is a necessary requirement for publication that at least one of the authors must be a member of PRRES.

Click here to see membership details. 


\title{
Pacific Rim Property Research Journal
}

\section{The official journal of the Pacific Rim Real Estate Society}

\section{A refereed journal in property ISSN 1444-8921}

\section{Volume 17 Number 4 December 2011}

\author{
AUTHOR: Chyi Lin Lee and Xiao-Hua Jin \\ TITLE: Exploring Australian Housing Supply Volatility
}

ABSTRACT: "This study examines the volatility series of housing supply in Australia. A Generalised Autoregressive Conditional Heteroskedasticity-in-Mean (GARCH-M) model is employed to analyse the volatility series of Australian housing supply over the study period of 1974-2010. The results show the volatility of housing starts is negatively linked to housing starts, suggesting that higher uncertainty does lower housing starts. The results also reveal that the uncertainty of housing starts is also captured by the volatilities of interest rates and construction costs. Therefore policy makers should monitor and attempt to minimise the volatility of housing supply. These steps will enhance housing construction activities and increase the availability of housing supply to potential home buyers."

View the Full Paper

AUTHOR: Janine Irons and Lynne Armitage

TITLE: "The Value Of Built Heritage: Community, Economy and Environment"

ABSTRACT: "Heritage protection in Australia was initiated by community groups such as the National Trust before the legislatures at each tier of government established the statutory controls now evident. Professional bodies in the built environment arena have also generated international guidelines in recent times with the adoption of standardised approaches to valuation and management practices for heritage property attesting to the acknowledgement of their special value and the recognition of characteristics common to diverse cultures. The objective of this paper is to review elements of our perceptions of heritage reflecting value which incorporate yet transcend the merely economic. It identifies the framework of heritage management in Australia and considers the many meanings of the relevant terminology. The traditional view is then extended to consider the potential environmental benefits of heritage conservation, contributing a contemporary commentary to some economic, social and professional concerns and reflects upon the challenges of the journey yet to come."

View the Full Paper

AUTHOR: Laura Cummins and Hugh Zochling

TITLE: Distribution Payout Practices and The Collapse Of A-REITS

ABSTRACT: "In the lead up to the Global Financial Crisis, A-REITS pursued aggressive distribution practices. Payout ratios significantly in excess of $100 \%$ of underlying earnings became common place, funded largely from increased borrowings. The GFC painfully exposed the unsustainability of this practice. A-REITs were punished when the global debt markets froze and property values crashed, leading to massive equity destruction for over geared A-REITs. This research explores the pre-GFC distributions practices of A-REITs. Annual report financial data analysis and semi-structured interviews with five industry experts were conducted to examine A-REIT distribution practices. The results reveal a clear systematic decline in the relationship between underlying earnings and distributions. It is further discovered that the since abandoned practice of distributing un-realised profits was designed to boost share prices. Paradoxically, it eventually led to their decline and the A-REIT sector's demise." 
AUTHOR: Lawrence Chin and Yu Kok Soon TITLE: Event Study Of Successful Land Tenders: Singapore'S Evidence From 2003 To 2010

ABSTRACT: "This paper adopts the event study methodology in examining the market reaction of the stock price of the winning tenderer from the announcement of the tender win. The companies studied are those listed in the Singapore Stock Exchange (SGX) during the period between 2003 and 2010. The findings from the study show that land tender win announcements resulted in positive abnormal return for the winning companies' stock prices. The underlying factors which are responsible for the positive abnormal return are the level of experience of the winning tenderer, level of uncertainty of the development, number of participating bidders and the type of land zoning for the site. On the other hand, a negative relationship is observed between the bid margin and the abnormal return. The higher the margin, the lower the return will be."

View the Full Paper

\section{AUTHOR: "Dulani Halvitigala, Laurence Murphy and Deborah Levy" \\ TITLE: The Impacts of Commercial Lease Structures On Landlord and Tenant Leasing Behaviours and Experiences}

ABSTRACT: "The commercial property market in New Zealand is characterized by two standard but distinct lease environments. In Auckland, the commercial core of the economy, net leases dominate, whereas in Wellington, the political capital, gross leases are dominant. These different lease environments have the potential to strongly influence the nature of landlord and tenant relationships in these markets. Using in-depth interviews with key industry personnel, this study examines the perceptions, behaviours, experiences and key issues confronting landlords and tenants under net and gross leases. The paper examines how different lease structures affect the behavioural and attitudinal characteristics of landlords and tenants including: landlord/tenant perceptions of a lease, the operation and maintenance procedures, landlord-tenant relationship, and ultimately, overall satisfaction."

View the Full Paper

AUTHOR: Graeme Newell and Chyi Lin Lee

TITLE: The Impact Of Alternative Assets On The Role Of Direct Property In Australian Mixed-Asset Portfolios

ABSTRACT: "Australian superannuation funds have increased their allocations to the alternative assets in recent years; this includes private equity, infrastructure, hedge funds and commodities. This raises the issue of whether this increased allocation to these alternative assets impacts on the strategic role and allocation of direct property in the Australian mixed-asset portfolio, due to the potential increased competition between these assets. This paper assesses the risk-adjusted performance and portfolio diversification benefits of direct property and various alternative assets over 1995-2009 and their role in optimal mixed-asset portfolios. While direct property is still seen to play a key role in the portfolio, direct property plays a less significant role in the portfolio when the alternative assets are included. In particular, Australian unlisted infrastructure and listed infrastructure are seen as key alternative assets across a significant portion of the portfolio risk spectrum. This is seen as validating the investment strategy of Australian superannuation funds who have significant exposure to the infrastructure sector."

View the Full Paper

AUTHOR: "Azlina Binti Md. Yassin, Sandy Bondand John Mcdonagh"

TITLE: Developing Guidelines For Riverfront Developments For Malaysia

ABSTRACT: "Rivers and water are important resources for human life, the environment and national development. In Malaysia, the importance of rivers as the focal point of cities was established from the early times of civilisation and will remain so. Population growth, economic growth, urbanisation and increased technology have transformed many Malaysian river systems from water industries into non water 
industries. Due to these changes, the functions of riverfront areas have also changed and the current pattern of riverfront development in Malaysia now focuses more on mixed-use development and recreation. To date, numbers of riverfront development projects are being developed in Malaysia for recreation, residential and mixed-use. Unfortunately, in most cases, the developments identified are not successful, having cost effects more than their economic value. Example are increases in water pollution indexes and rates of juvenile problems. The focus of this study was to identify the attributes of riverfront development, in order to develop guidelines for riverfront development for Malaysia. The findings of this study were based on interviews conducted with Government officers, Property developers, and the Waterfront community from three case study areas (qualitative phase), and from questionnaires mailed and e-mailed to property development companies listed under Bursa Malaysia (quantitative phase). The findings identified 18 attributes to be used in assisting developers when undertaking riverfront projects in the future. The attributes identified were then recommended to be used as guidelines of best practices of riverfront development in Malaysia."

View the Full Paper

AUTHOR: Georgia Warren-Myers

TITLE: Sustainability - The Crucial Challenge For The Valuation Profession

ABSTRACT: "Sustainability, strategic knowledge development, valuation practice" View the Full Paper 